\title{
Perbandingan Penggunaan Dua Jenis Ransum terhadap Pertambahan Bobot Badan Harian (PBBH) Konsumsi Ransum dan Konversi Ransum Broiler
}

Kanisius Otemusu ${ }^{\mathrm{a}}$

${ }^{a}$ Fakultas Pertanian, Universitas Timor, Kefamenanu, TTU - NTT, 85613, Indonesia.

\section{Article Info}

Article history:

Received 20 Mei 2018

Received in revised form 27 Juni 2018

Accepted 1 Juli 2018

DOI

https://doi.org/10.32938/ja.v3i3.542

Keywords:

Ransum Buatan

Ransum Komersial

Ayam Broiler

\begin{abstract}
Abstrak
Penelitian ini telah dilaksanakan dikandang milik Program Studi Peternakan, Fakultas Universitas Timor, Kabupaten Timor Tengah Utara. Penelitian ini berlangsung selama 42 hari yang mulai dari bulan Maret sampai dengan April 2016. Penelitian ini menggunakan ternak Broiler sebanyak 80 ekor. Tujuan penelitian ini adalah untuk membandingkan kualitas ransum yang dibuat sendiri dengan ransum komersial terhadap pertambahan bobot badan harian $(\mathrm{PBBH})$, konsumsi ransum dan konversi ransum. Metode penelitian yang digunakan adalah data primer berupa data yang diperoleh dari pengamatan langsung yang dilakukan dengan menguji ransum buatan dan ransum komersial. Hasil penelitian ini menunjukkan rata-rata pertambahan bobot badan untuk perlakuan ransum buatan adalah 147,66 g dan perlakuan ransum komersial $149,90 \mathrm{~g}$. Konsumsi ransum perlakuan ransum buatan 99,88 g, perlakuan ransum komersial 101,384 g. Ratarata konversi ransum untuk perlakuan ransum buatan adalah 0,68 dan perlakuan ransum komersial adalah 0,68 . Ransum buatan dan komersil memiliki keunggulan yang sama dalam menghasilkan berat badan, konsumsi ransum dan konversi ransum. Pemanfaatan bahan baku lokal seperti tepung gaplek, tepung daun turi, jagung giling, dedak padi, kunyit dan tepung ikan sangat efektif untuk dimanfaatkan sebagai ransum ternak ayam broiler.
\end{abstract}

\section{Pendahuluan}

Permintaan ayam broiler di Timor Tengah Utara saat ini mengalami kemajuan yang sangat pesat. Permintaan tersebut dikarenakan semakin meningkatnya kebutuhan masyarakat akan daging sebagai salah satu sumber protein. Ayam broiler adalah ayam ras yang sengaja dibibitkan dan di kembangkan untuk mendapatkan daging yang cepat di bandingkan dengan unggas lain (Zulkarnaen, 2013). Dewasa ini para peternak ayam broiler masih menggunakan ransum komersial yang dibeli dengan harga yang cukup mahal namun kualitas nutrisi yang tidak efisien sehingga memberikan dampak negatif bagi para peternak. Oleh karena itu peternak sering mengalami keterlambatan produksi sehingga membawa pada kerugian ekonomi.

Ransum merupakan campuran dari berbagai macam bahan pakan yang siap diberikan kepada ternak untuk memenuhi kebutuhan nutrien selama 24 jam tanpa menimbulkan efek samping pada kesehatan ternak. Ransum memegang peranan sangat penting dalam usaha pembesaran atau penggemukan ayam broiler. Pasalnya, ransumlah yang menentukan pertambahan bobot badan ayam broiler. Karena itu ransum yang diberikan pada ayam broiler harus berkualitas (Fadilah, 2013). Ayam broiler adalah ayam ras yang sengaja dibibitkan dan d kembangkan untuk mendapatkan daging yang cepat di bandingkan dengan unggas lain (Zulkarnaen, 2013).

Beberapa parameter yang didapat melalui pemeliharaan broile diantaranya peningkatan bobot badan rata-rata sehingga total bobot ayam yang dipanen meningkat, menurunnya angka konversi ransum (Ration conversion) sehingga pakan yang dibutuhkan selama pemeliharaan menurun.

Pertambahan bobot badan ditentukan dengan cara mengurangkan bobot badan akhir dengan bobot badan awal. Kecepatan pertumbuhan memiliki varias yang cukup besar. Keadaan ini tergantung pada tipe ayam, jenis kelamin, galur, tatalaksana, temperatur lingkungan, tempat ayam tersebut di pelihara, serta kualitas dan kuantitas ransum. Konversi ransum (Ration Conversion) adalah perbandingan jumlah konsumsi ransum pada satu minggu dengan pertambahan bobot badan yang dicapai pada minggu itu. Bila rasio kecil berarti pertambahan bobot badan ayam memuaskan atau ayam makan dengan efisien.

Penggunaan bahan pakan lokal seperti tepung gaplek, dedak padi, tepung ikan, tepung daun turi dan jagung giling sebagai bahan pakan dasar yang diolah menjadi ransum buatan sendiri diharapkan membawa dampak yang positif terhadap peningkatan bobot badan ayam broiler.

\section{Metode}

Penelitian ini dilaksanakan di kandang unggas milik Program Studi Peternakan, Fakultas Pertanian, Universitas Timor dan berlangsung selama 42 hari. Ternak yang dipakai dalam penelitian ini adalah Day Old Chick (DOC) strain CP 707 produksi PT. Charoen Phokpan sebanyak 80 ekor.

Ransum ayam broiler terbagi menjadi dua jenis yaitu ransum untuk periode starter dan ransum untuk periode finisher (Murtidjo, 1991). Bahan yang digunakan dalam penelitian ini terdiri ransum komersial, pakan disusun berdasarkan kebutuhan ternak ayam (Tabel 1.) yaitu BR-1 diberikan pada umur 0 - 4 minggu untuk ternak pada fase starter dan BR-2 diberikan pada umur 4 - 6 minggu untuk ternak pada fase finisher, sedangkan pada ransum buatan menggunakan bahan berupa tepung gaplek, jagung giling, tepung ikan, dedak padi, tepung daun turi, molases dan premix dan minyak kelapa dengan nila nutrisi bahan baku lokal ransum buatan terlihat pada Tabel 2. Vaksin yang akan digunakan terdiri dari 2 jenis vaksin yaitu ND Lasota (umur 4 hari dengan sistem tetes mata) dan ND IB (umur 21 hari yang dilakukan dengan sistem penyuntikan pada paha). Peralatan yang digunakan adalah alat ukur berupa timbangan duduk kapasitas $2 \mathrm{~kg}$ untuk menimbang ransum yang diberikan, dan sisa ransum, timbangan analitik kapasitas $2 \mathrm{~kg}$ untuk menimbang berat badan harian. Alat pencetakan ransum berbentuk pellet serta kandang tipe lantai dengan mode lorong yang terdiri dari 16 petak. Tiap petak kandang berukuran 1 x $0,5 \mathrm{~m}$. Seka antara petak berukuran $50 \mathrm{~cm}$ dari permukaan lantai, tiap petak kandang dilengkapi tempat makan dan minum serta pemanas menggunakan lampu pijar 100 watt.

Tabel 1. Kebutuhan Nutrisi Pakan Ayam Broiler.

\begin{tabular}{llcc}
\hline No. & Nutrisi & Periode starter & Periode finisher \\
\hline 1 & Protein ( \% ) & $22,00 \%$ & $20,00 \%$ \\
2 & Gross energy (kkal/kg) & $2800-3200$ & $2900-3200$ \\
3 & Kalsium ( \% ) & 1,00 & 0,90 \\
4 & Fosfor (\%) & 0,45 & 0,35 \\
\hline
\end{tabular}

Sumber: (Anita \& Widagdo, 2011).

Tabel 2. Nilai Nutrisi Bahan Baku Lokal Ransum Buatan

\begin{tabular}{|c|c|c|c|c|c|c|c|}
\hline No. & Bahan & Gross Energy & PK & LK & BK & SK & Kalsium \\
\hline 1 & Gaplek & $2.600 \mathrm{kkal}$ & 1,7 & - & & 1,6 & 0,12 \\
\hline 2 & Daun turi & - & 40,62 & 5,66 & 28,3 & 10,67 & 0,18 \\
\hline 3 & Jagung kuning & $3.430 \mathrm{kkal}$ & 9,0 & 4,23 & 86,80 & 2,53 & \\
\hline 4 & Dedak & & 10,40 & 8,10 & 88,60 & 10,60 & - \\
\hline 5 & Tepung ikan & & 61,80 & 7,43 & 87,30 & 2,10 & - \\
\hline
\end{tabular}

Sumber: (Wahju, 2004)

Penelitian ini menggunakan model experimen dimana perlakuan yang diuji terdiri dari :

$\mathrm{X} 1$ = Ransum buatan

$\mathrm{X} 2$ = Ransum komersial

Setiap perlakuan yang diuji pada 8 petak kandang dimana setiap petak terdiri dari 5 ekor ayam Broiler. Pembuatan ransum diawali dengan menyiapkan bahan baku lokal yang telah dibuat dalam bentuk tepung seperti tepung jagung, tepung gaplek, tepung ikan, tepung daun turi, tepung kunyit. Selanjutnya bahan yang ada dicampur secara manual sampai terlihat homogen. Campuran bahan diberi larutan molases, probiotik dan minyak kelapa. Ransum yang telah dicampur diberi larutan kanji sambil dipercikkan air sampai campuran bahan tampak basah bila dikepal. Selanjutnya ransum dicetak dengan menggunakan mesin pelleting dengan ukuran $0,5 \mathrm{~cm}$. Pellet yang telah dicetak kemudian dijemur selama 1 hari selanjutnya dimasukkan dalam oven dengan suhu $70^{\circ} \mathrm{C}$ selama 2 hari.

Pada tahap awal ternak ayam broiler diberi larutan air gula untuk mengurangi dampak stres selama perjalanan. Ayam broiler ditempatkan pada 2 petak kandang komunal dimana setiap petak kandang komunal berisi 40 ekor. Selama 5 hari ternak sudah mulai dibiasakan dengan ransum yang akan diuji selanjutnya pada hari ke 6 dipindahkan ke dalam petak pembagi dimana setiap petak diisi ayam broiler sebanyak 5 ekor. Ransum yang diuji dalam penelitian in berupa ransum buatan dan ransum komersial. Pemberian ransum pada minggu pertama dan kedua sebanyak $300 \mathrm{~g} /$ petak untuk setiap jenis ransum, selanjutnya pada minggu ke 3 diberikan 500 gram/petak, minggu ke 4 diberikan 800 gram/petak dan minggu ke 5 diberikan $1000 \mathrm{~g} /$ petak. Data pertambahan bobot badan diambil pada tiap minggu dengan melakukan penimbangan pada ternak (g/ekor/hari), sedangkan data konsumsi ransum di ambil dengan menghitung selisih antara pemberian dan sisa. Penimbangan sisa ransum dilakukan setiap hari. Pertambahan berat badan (g/ekor/hari), Konsumsi ransum (g/ekor/hari), Konversi pakan (g) merupakan variabel yang diamati dalam penelitian ini. Data dianalisis menggunakan analisis deskriptif yaitu menghitung nilai rata - rata dari masing - masing variabel, standar deviasi dan koefisien keragaman dengan formulasi masing - masing berdasarkan Sugiyono (2000). Sedangkan untuk membandingkan produktivitas ransum yang dibuat sendiri dengan ransum komersial digunakan uji T (T-test) berdasarkan petunjuk Soematri \& Muhidin (2006). 


\section{Hasil dan Pembahasan}

\subsection{Pertambahan bobot badan (g/ekor/hari)}

Pertambahan bobot badan adalah selisih antara berat badan akhir dengan berat badan awal dibagi lama waktu penelitian (gr/ekor/hari). Rata-rata pertambahan bobot badan Broiler terlihat pada Tabel 3 .

\begin{tabular}{crrrr}
\multicolumn{6}{c}{ Tabel 3. Rata-rata Pertambahan Bobot Badan Hasil Penelitian (g/ekor/hari) } \\
\hline No. Petak & $\mathrm{X}_{1}$ & $\mathrm{X}_{2}$ & $\mathrm{X}_{1}{ }^{2}$ & $\mathrm{X}_{2}{ }^{2}$ \\
\hline 1 & 147.16 & 149.43 & 21655.9 & 22328.71 \\
2 & 146.94 & 149.82 & 21590.02 & 22447.37 \\
3 & 147.02 & 150.54 & 21615.97 & 22661.1 \\
4 & 148.71 & 150.92 & 22114.58 & 22776.5 \\
5 & 147.70 & 150.89 & 21816.72 & 22768.36 \\
6 & 147.54 & 150.00 & 21769.4 & 22498.95 \\
7 & 147.83 & 149.76 & 21854.3 & 22429.1 \\
8 & 148.36 & 147.88 & 22011.54 & 21867.53 \\
\hline Jumlah & 1181.27 & 1199.24 & 174428.43 & 179777.63 \\
\hline Rataan & 147.66 & 149.90 & 21803.55 & 22472.20 \\
\hline SD & 0.63 & 0.98 & 187.65 & 294.08 \\
\hline KK & 0.43 & 0.66 & 0.86 & 1.31 \\
\hline
\end{tabular}

Keterangan: X1: Ransum Buatan; X2: Ransum Komersial

Pada Tabel 3. terlihat bahwa rata-rata pertambahan berat badan broiler pada perlakuan ransum buatan adalah $147,66 \mathrm{~g} / \mathrm{ekor} / \mathrm{hari}$ dan rata-rata pertambahan bobot badan pada perlakuan ransum komersial adalah 149,90 gram/ekor/hari atau selisih pertambahan kedua perlakuan ini adalah 2,24 gram/ekor/hari. Nilai standar deviasi (SD) dan koefisien keragaman (KK) pada pertambahan bobot badan harian terendah diperoleh pada perlakuan ransum buatan yaitu masing-masing 0,63 dan 0,43 sedangkan pada ransum komersial masing-masing 0,98 dan $0,66 \%$. Dari hasil tersebut menunjukkan bahwa kedua jenis ransum ini menghasilkan nilai keragaman yang relatif sama atau dengan kata lain bahwa tidak terdapat perbedaan keragaman baik pada ransum buatan maupun ransum komersial.

Hasil analisis Uji T (T-test) menunjukkan bahwa perbedaan pertambahan bobot badan antara kedua perlakuan tidak berbeda nyata $(\mathrm{P}>0,05)$. Hal ini menunjukkan bahwa ransum buatan mampu mengimbangi kemampuan ransum komersial dalam menghasilkan berat badan ternak. Hal ini karena semua bahan yang berasal dari bahan baku lokal seperti tepung gaplek, jagung giling, tepung daun turi, tepung ikan, kunyit, minyak kelapa serta molases memiliki nilai nutrisi yang lengkap sehingga mampu memberikan nilai pertambahan bobot badan yang baik. Seiring dengan pendapat (Zulkarnaen, 2013) yang menyatakan bahan pakan yang diberikan pada ternak yang memiliki nilai kandungan nutrisi yang lengkap seperti karbohidrat, lemak, protein, asam amino, vitamin, serta air seimbang dan tepat sesuai kebutuhan ayam broiler maka akan memberikan nilai pertambahan bobot badan ayam yang memuaskan. Selanjutnya (Wahju, 2004) berpendapat bahwa nilai energi metabolisme, protein, mineral, air, lemak yang tersedia dalam pakan mempunyai tujuan yaitu untuk kebutuhan pokok, pertumbuhan dan penggemukan.

\subsection{Pengaruh Perlakuan terhadap Konsumsi Ransum (g/ekor/hari)}

Konsumsi ransum adalah selisih antara jumlah pakan yang diberikan dan pakan sisa yang tidak dimakan dibagi total lama penelitian (gram/ekor/hari). Pada Tabel 4. terlihat bahwa rata-rata konsumsi ransum pada perlakuan ransum buatan adalah 99,81 g/ekor/hari dan rata-rata konsumsi ransum pada perlakuan ransum komersial adalah 101,38 g/ekor/hari atau selisih 1,57 gram/ekor/hari. Nilai standar deviasi (SD) dan koefisien keragaman (KK) pada konsumsi ransum terendah diperoleh pada perlakuan ransum buatan yaitu masing-masing $0,32 \%$ dan $0,32 \%$ sedangkan pada ransum komersial masing-masing $0,28 \%$ dan $0,28 \%$. Dari hasil tersebut menunjukkan bahwa kedua jenis ransum ini menghasilkan nilai keragaman yang sama atau dengan kata lain bahwa tidak terdapat perbedaan keragaman dari sisi konsumsi baik pada ransum buatan maupun ransum komersial.

Hasil analisis Uji T (T-test) menunjukkan bahwa perbedaan konsums ransum antara kedua perlakuan ini berbeda tidak nyata $(\mathrm{P}>0,05)$, sehingga dapat dikatakan bahwa ransum buatan memiliki nilai palatabilitas yang hampir sama dengan ransum komersial. Hal ini karena pengolahan ransum mampu menciptakan nilai cita rasa yang tinggi dan disukai oleh ternak, selain itu penggunaan bahan berenergi tinggi seperti jagung dan ubi kayu mampu mengimbangi energi pada ransum buatan. Hal ini didukung oleh Suprijatna, (2005) bahwa perbedaan kandungan protein menyebabkan broiler akan mengkonsumsi ransum yang lebih banyak jika kebutuhan energinya belum tercukupi untuk maintenance, metabolisme, produksi, dan lain - lain. Dilanjutkan oleh Sidadolog (1999) ayam akan berhenti mengkonsumsi ransum jika kebutuhan energi telah terpenuhi. Sekalipun pakan didalam temboloknya kosong namun energi di dalam tubuh telah terpenuhi maka ayam akan berhenti mengkonsumsi ransum. Pakan buatan yang diramu sendiri dalam penelitian ini terdiri dari bahan-bahan lokal yang memiliki keunggulan dalam komposisi nutrisi seperti yang terkandung dalam tepung ikan dan tepung gaplek.

\subsection{Pengaruh Perlakuan Terhadap Konversi Ransum}

Konversi ransum (Ration Conversion) adalah perbandingan jumlah konsumsi ransum pada satu minggu dengan pertambahan bobot badan yang dicapai pada minggu itu, bila rasio kecil berarti pertambahan bobot badan ayam memuaskan atau ayam makan dengan efisien. Hal ini dipengaruhi oleh besar badan dan bangsa ayam, tahap produksi, kadar energi dalam ransum, dan temperatur lingkungan (Jayananta \& Harianto, 2011). Nilai rata-rata konversi ransum terlihat pada Tabel 5.

\begin{tabular}{crrrr}
\multicolumn{6}{c}{ Tabel 4. Rata-rata Konsumsi Ransum Hasil Penelitian (g/ekor/hari) } \\
\hline Petak & $\mathrm{X}_{1}$ & $\mathrm{X}_{2}$ & $\mathrm{X}_{1}{ }^{2}$ & $\mathrm{X}_{2}{ }^{2}$ \\
\hline 1 & 100.00 & 101.09 & 10000.00 & 10218.32 \\
2 & 99.77 & 101.31 & 9954.34 & 10264.58 \\
3 & 99.94 & 101.49 & 9988.57 & 10299.35 \\
4 & 100.23 & 102.00 & 10045.77 & 10404.00 \\
5 & 99.37 & 101.43 & 9874.68 & 10287.76 \\
6 & 100.17 & 101.26 & 10034.32 & 10253.01 \\
7 & 99.49 & 101.20 & 9897.41 & 10241.44 \\
8 & 99.54 & 101.26 & 9908.78 & 10253.01 \\
\hline Jumlah & 798.51 & 811.03 & 79703.86 & 82221.47 \\
\hline Rataan & 99.81 & 101.38 & 9962.98 & 10277.68 \\
\hline SD & 0.32 & 0.28 & 64.45 & 57.01 \\
\hline KV & 0.32 & 0.28 & 0.65 & 0.55 \\
\hline Keterangan $:$ & X1: Ransum Buatan X2 $\cdot$ Ransum Komersial &
\end{tabular}

Keterangan : X1: Ransum Buatan; X2: Ransum Komersial

\begin{tabular}{ccccc}
\multicolumn{5}{c}{ Tabel 5. Rata-rata Konversi Ransum Ayam Broiler (g/ekor/hari) } \\
\hline Petak & $\mathrm{X}_{1}$ & $\mathrm{X}_{2}$ & $\mathrm{X}_{1}{ }^{2}$ & $\mathrm{X}_{2}{ }^{2}$ \\
\hline 1 & 0.68 & 0.68 & 0.46 & 0.46 \\
2 & 0.68 & 0.68 & 0.46 & 0.46 \\
3 & 0.68 & 0.67 & 0.46 & 0.45 \\
4 & 0.67 & 0.68 & 0.45 & 0.46 \\
5 & 0.67 & 0.67 & 0.45 & 0.45 \\
6 & 0.68 & 0.68 & 0.46 & 0.46 \\
7 & 0.67 & 0.68 & 0.45 & 0.46 \\
8 & 0.67 & 0.68 & 0.45 & 0.47 \\
\hline Jumlah & 5.41 & 5.41 & 3.66 & 3.66 \\
\hline Rataan & 0.68 & 0.68 & 0.46 & 0.46 \\
\hline SD & 0.00 & 0.00 & 0.00 & 0.00 \\
\hline KV & 0.54 & 0.54 & 1.08 & 1.09 \\
\hline Keterangan & X1: Ran & & &
\end{tabular}

Keterangan: X1: Ransum Buatan

X2: Ransum Komersial

Pada Tabel 5. terlihat bahwa ternak ayam Broiler yang mendapat perlakuan ransum buatan maupun ransum komersial memiliki nilai konversi yang sama yaitu 0,68, (Zulkarnaen, 2013) yang mengatakan nilai konversi ransum (Ration Conversion) adalah perbandingan jumlah konsumsi ransum pada satu minggu dengan pertambahan bobot badan yang dicapai pada minggu itu. Apabila nilai konversi lebih rendah dari nilai patokan standar maka dikatakan bahwa kualitas pakan berhasil dan efisien.

Nilai standar deviasi (SD) dan koefisien keragaman (KK) konversi ransum baik ransum buatan maupun komersial tidak berbeda yaitu masing 0,00 dan 0,54 kesamaan nilai ini disebabkan karena nilai rataan konversi ransum pada ransum buatan dan komersial tidak berbeda. Dari hasil tersebut menunjukkan bahwa kedua jenis ransum ini menghasilkan nilai keragaman yang relatif sama atau dengan kata lain bahwa tidak terdapat perbedaan keragaman baik pada ransum buatan maupun ransum komersial.

Hasil analisis uji $\mathrm{T}$ (T-test) menunjukkan bahwa nilai konversi ransum antara kedua perlakuan ini tidak berbeda nyata $(\mathrm{P}>0,05)$. Ini berati setiap gram ransum buatan dan ransum komersial yang diuji memiliki kemampuan yang sama diubah menjadi berat badan.

\section{Simpulan}

Rata-rata pertambahan berat badan broiler pada perlakuan ransum buatan adalah 147,66 g/ekor/hari dan rata-rata pertambahan bobot badan pada perlakuan ransum komersial adalah 149,90 g/ekor/hari atau selisih pertambahan kedua perlakuan ini adalah 2,25 g/ekor/hari sedangkan rata-rata konsumsi ransum pada perlakuan ransum buatan adalah 99,81 g/ekor/hari dan rata-rata konsumsi ransum pada perlakuan ransum komersial adalah 101,38 g/ekor/hari atau selisih 1,57 g/ekor/hari. Rata-rata nilai konversi ransum buatan adalah 0,68 dan perlakuan ransum komersial yang nilai konversinya adalah 0,68. Ransum buatan dan komersil memiliki keunggulan yang sama dalam menghasilkan berat badan, konsumsi ransum dan konversi ransum. Pemanfaatan bahan baku lokal seperti tepung gaplek, tepung daun turi, jagung giling, dedak padi, kunyit dan tepung ikan sangat efektif untuk dimanfaatkan sebagai ransum ternak ayam broiler.

\section{Pustaka}

Anita, S., Widagdo, W., 2011. Budidaya Ayam Broiler 28 hari panen. Pinang merah Publisher. Yogyakarta.

Fadilah, R., 2013. Beternak Ayam Broiler. Agro Media Pustaka, Jakarta.

Jayanata, C. E.\& B. Harianto. 2011. 28 Hari Panen Ayam Broiler. PT Agromedia Pustaka. Jakarta.

Murtidjo B. A. 1991. Pedoman Beternak Ayam Broiler. Kanisius. Yogyakarta.

Sidadolog J. H. P. 1999. Menajemen Ternak Unggas. Hand Out. Fakultas Peternakan UGM. Yogyakarta.

Soematri, Muhidin, 2006. Teknik Analisis Dalam Penelitian Percobaan. Tarsito. Bandung. 
Sugiyono, 2000. Statistik untuk Penelitian (cetakan ke 3). Alfabeta: Bandung.

Suprijatna, E. 2005. Pengaruh Protein Ransum Saat Periode Pertumbuhan Terhadap Performans Produksi Telur Saat Periode Produksi Pada Ayam Ras Petelur Tipe Medium. Fakultas Peternakan, UNDIP

Wahju, J., 2004. Ilmu Nutrisi. Gadja Mada University Press, Yogyakarta.

Zulkarnaen, D., 2013. Lebih Sukses dan Untung Beternak Ayam Broiler. Dafa Publishing, Surabaya. 